\title{
Incidental fishing mortality may be responsible for the death of ten billion juvenile sea scallops in the mid-Atlantic
}

\author{
Kevin D. E. Stokesbury*, Jonathan D. Carey, Bradley P. Harris, \\ Catherine E. O'Keefe
}

\begin{abstract}
Department of Fisheries Oceanography, School for Marine Science and Technology, University of Massachusetts, Dartmouth, 706 South Rodney French Boulevard, New Bedford, Massachusetts 02744-1221, USA
\end{abstract}

\begin{abstract}
A single large year class in the mid-Atlantic consisting of an estimated $1.31 \times 10^{10}$ sea scallops was observed in 2003. This year class was 1.1 to 1.6 times larger than the entire scallop stock in any year between 2004 and 2009. Over half of these scallops vanished between 2003 and 2004 This apparent mortality episode was not likely to have been caused by a shift in environmental conditions or by biological factors such as predation, senescence, or food limitation. However, the bulk of fishing effort during that year was focused on the mid-Atlantic. During fishing operations these scallops were brought to the surface through water temperatures above the lethal limit and exposed to high air temperatures before being returned to the sea floor several hours later. Therefore, this mass mortality was likely the result of incidental fishing mortality. The recruitment event was reported to managers on 2 July 2003; however, the area remained open to fishing for another 13 mo before the Elephant Trunk Closed Area was established. Although the Elephant Trunk Closed Area has provided substantial landings for the past $5 \mathrm{yr}$, the potential of the 2003 recruitment event was only partially realized. Achieving the full benefit of extreme recruitment events requires close ecological monitoring of the target species, real-time abundance and size distribution data, and a management system that can respond rapidly.
\end{abstract}

KEY WORDS: Sea scallop · Placopecten magellanicus · Video survey · Georges Bank · Closed areas · Incidental fishing mortality $\cdot$ Mass mortality

\section{INTRODUCTION}

The sea scallop Placopecten magellanicus fishery of New England, USA, is presented as a management success (e.g. Hart \& Rago 2006). Landings, which had dropped from $17288 \mathrm{t}$ in 1991 to $5564 \mathrm{t}$ in 1998, have rebounded to an average of $26129 \mathrm{t}(\mathrm{SD}=1489.3 \mathrm{t})$ from 2003 to 2009, worth $>\$ 300$ million USD annually (NMFS 2010). This recovery has been attributed to a combination of effort controls and area management (Hart \& Rago 2006). Sea scallop landings in Canada and the United States have historically been driven by large year classes, which occur in cyclical, irregular, or spasmodic patterns (Caddy 1989).
Sea scallops are highly fecund, gonochoristic broadcast spawners with pelagic larvae; abundances may increase dramatically when conditions favor reproduction and survival (Caddy 1989). These attributes, coupled with low mortality rates (Merrill \& Posgay 1964), fast growth rates (summarized in Caddy 1989 and Harris \& Stokesbury 2006), and limited movement (Posgay 1981, Stokesbury \& Himmelman 1996), make the scallop's life history well suited to rotational management strategies (Hart \& Rago 2006).

High incidental fishing mortality, totaling $70 \%(Z=$ 1.2), was reported for a scallop recruitment event on Georges Bank's Northern Edge in 1970 (Caddy 1971, 1972). However, Murawski \& Serchuk (1989) observed 
little evidence of incidental fishing mortality in the mid-Atlantic. Hart \& Rago (2006) hypothesize that if incidental fishing mortality is high, there should be a difference in the survival rates of pre-recruit scallops inside compared to outside closed areas; they found no statistical difference and concluded that incidental mortality in sea scallops is relatively low. Myers et al. (2000) suggested that a rotational management strategy has substantial benefits if incidental fishing mortality is high and not well quantified.

In June 2003, we observed an extremely high abundance of small scallops in the mid-Atlantic (Stokesbury et al. 2004). In July 2004, the Elephant Trunk Closed Area was established to protect this recruitment event (USA Federal Regulations 2004); however, less than half of the scallops observed in 2003 were observed in 2004. We examined the magnitude of this loss by comparing the 2003 scallop abundance to subsequent years. In the present study, we consider the possible causes, ramifications on the present scallop resource, and implications for management.

\section{MATERIALS AND METHODS}

The United States sea scallop resource in the midAtlantic and on Georges Bank was annually surveyed using video quadrats in a centric systematic sampling design from May to July, 2003 to 2009. Stations were positioned on a $5.6 \times 5.6 \mathrm{~km}(3.0 \times 3.0$ nautical mile $)$ grid overlying fishing grounds, based on information from commercial fishermen and the Vessel Monitoring System (Fig. 1; Rago et al. 2000, Stokesbury 2002, Stokesbury et al. 2004). The study area was divided into equal squares, and a sampling unit was taken from the center of each square; the location of the first sampling unit was randomly selected.

Surveys used DeepSea Multi SeaCam 2050 underwater video cameras mounted vertically on a pyramid; although the pyramid supports 3 video cameras, only the camera mounted $700 \mathrm{~mm}$ above the sea floor and providing a $0.60 \mathrm{~m}^{2}$ quadrat was used, as it provides the best sample of small scallops (Fig. 2; Stokesbury et al. 2004). To account for partially visible scallops observed on the edge of the image, we calculated the quadrat size by adding half the mean shell height of scallops in the area surveyed to each edge of the quadrat (Stokesbury et al. 2004, NMFS 2010). No edge correction was made for calculation of sea stars or crabs. Eight DeepSea lights (Multi SeaLight and ML3, DeepSea) provided illumination. The time, depth, number of live and dead scallops, macroinvertebrates, and latitude and longitude were recorded at each station.

After each survey the videotapes were reviewed in the laboratory and a still image of each quadrat was digitized. The field data were verified, and the shell height $(\mathrm{mm})$ of each scallop Placopecten magellanicus was measured in the still image using Image Pro Plus software. In these images scallops were identifiable to a size of $20 \mathrm{~mm}$ shell height.

Scallop mean density and variance were estimated using a 2-stage sampling design in which 4 quadrats (elements) are sampled within each station (primary unit). Since there are a constant number of quadrats at every station, the 2 -stage mean number of scallops is calculated as:

$$
\overline{\bar{X}}=\sum_{i=1}^{n}\left(\frac{\bar{x}_{i}}{n}\right)
$$

where $n$ is the number of stations and $\bar{x}_{i}$ is the mean of the 4 quadrats at $\operatorname{Stn} i$.

The standard error of this 2-stage mean is calculated as:

$$
\mathrm{SE}(\overline{\bar{x}})=\sqrt{\frac{1}{n}\left(s^{2}\right)}
$$

where $s^{2}=\sum(\bar{x}-\overline{\bar{X}})^{2} /(n-1)$.

According to Cochran (1977) and Krebs (1989) this simplified version of 2 -stage variance is appropriate when the ratio of the sample area to the survey area is small. In this case, 100s of square meters are sampled compared with millions of square meters in the survey areas. All calculations used scallops $\mathrm{m}^{-2}$. The scallop abundance within a survey area was calculated by multiplying scallop density by the total area surveyed (Stokesbury 2002).

Annual fishery harvest data were obtained from the NMFS Northeast Fisheries Science Center's 50th Stock Assessment Workshop for sea scallops (NMFS 2010). Recruits were defined as any scallop with a shell height of $<75 \mathrm{~mm}$ (based on shell height frequencies), the scallop's sexual maturity (gonad dry weight $>0.5$ g producing $>10$ million eggs; MacDonald \& Thompson 1985, Langton et al. 1987, McGarvey et al. 1992), and the confounding effect of the selectivity of the fishery operating with both $89 \mathrm{~mm}$ $\left(3.5^{\prime}\right)$ and $102 \mathrm{~mm}\left(4.0^{\prime}\right)$ rings in the dredge bag between 2003 and 2009. The dredge gear with a $102 \mathrm{~mm}$ ring in the 2005 and 2006 scallop fishery showed $50 \%$ retention at $100.1 \mathrm{~mm}$ shell height (Yochum \& DuPaul 2008).

\section{RESULTS}

Scallop Placopecten magellanicus abundance in the mid-Atlantic in 2003 was significantly higher than abundance in either the Georges Bank or mid-Atlantic stock areas in any year between 2004 and 2009 (ANOVA, $\mathrm{df}=13, F=13.269, \mathrm{p}<0.001$, power $=$ 0.050:1.00, Tukey's post-hoc test $\mathrm{p}<0.001$ for the 2003 

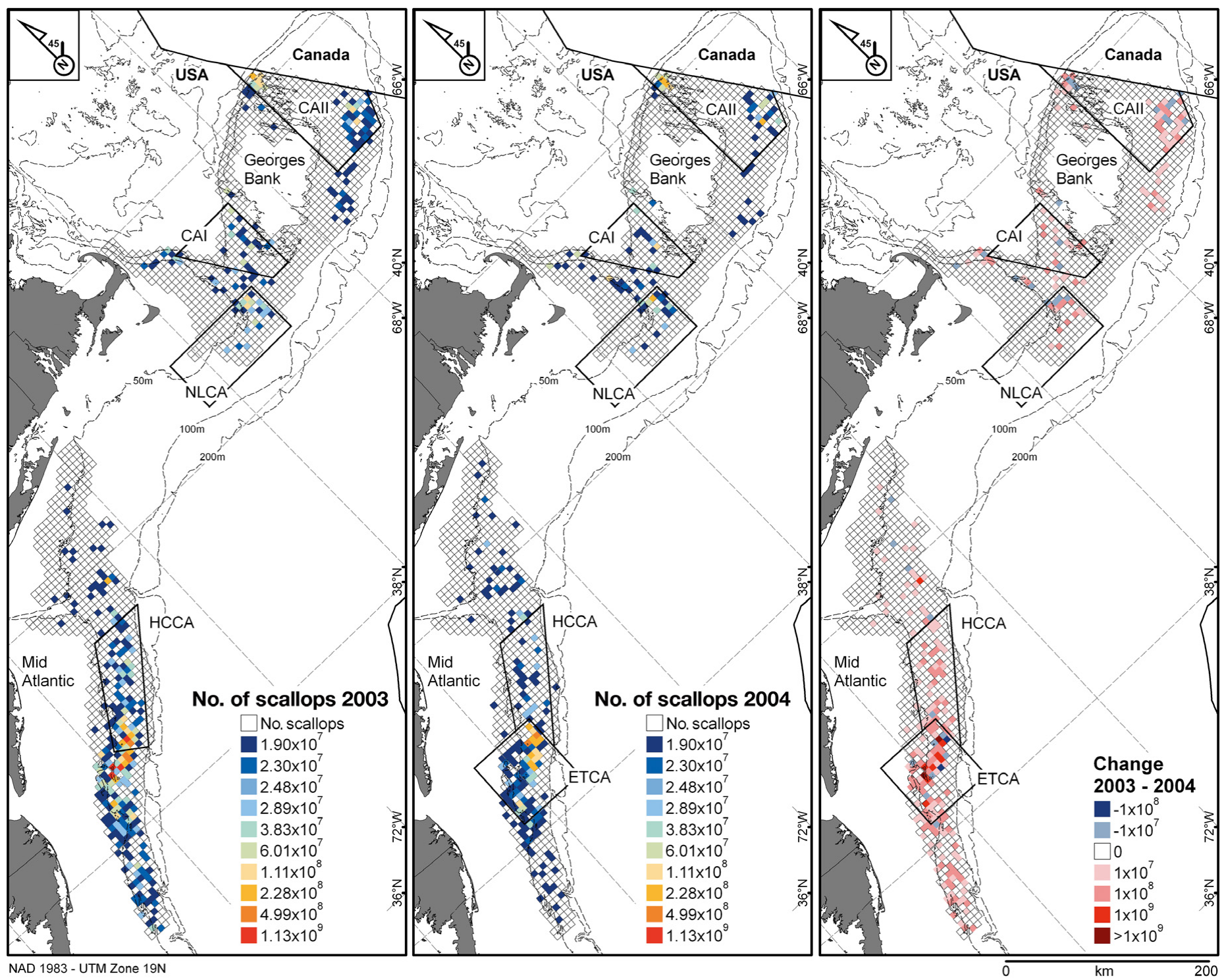

Fig. 1. Placopecten magellanicus. Comparison of sea scallop abundance and distribution observed in the video survey in 2003 and 2004 on Georges Bank and in the mid-Atlantic. Each square represents the video sampling grid $(5.6 \times 5.6 \mathrm{~km})$. The difference between abundance observed in 2003 and abundance observed in 2004 is presented in the far right panel. CAI: Closed Area I; CAII: Closed Area II; NLCA: Nantucket Lightship Closed Area; HCCA: Hudson Canyon Closed Area; ETCA: Elephant Trunk Closed Area

mid-Atlantic compared to all other years; Table 1). Of the estimated $1.74 \times 10^{10}$ scallops observed in the midAtlantic in $2003,75 \%\left(1.31 \times 10^{10}\right)$ were from 20 to $74 \mathrm{~mm}$ shell height (Figs. 3 \& 4). The abundance of this single recruitment event was 1.1 to 1.6 times greater than that of the entire scallop resource in any year between 2004 and 2009.

Fig. 2. Placopecten magellanicus. Digital image of a $0.6 \mathrm{~m}^{2}$ video quadrat containing 40 sea scallops on sand substrate in an area of extremely high recruitment in the mid-Atlantic in 2003, Stn 454, 1st quadrat

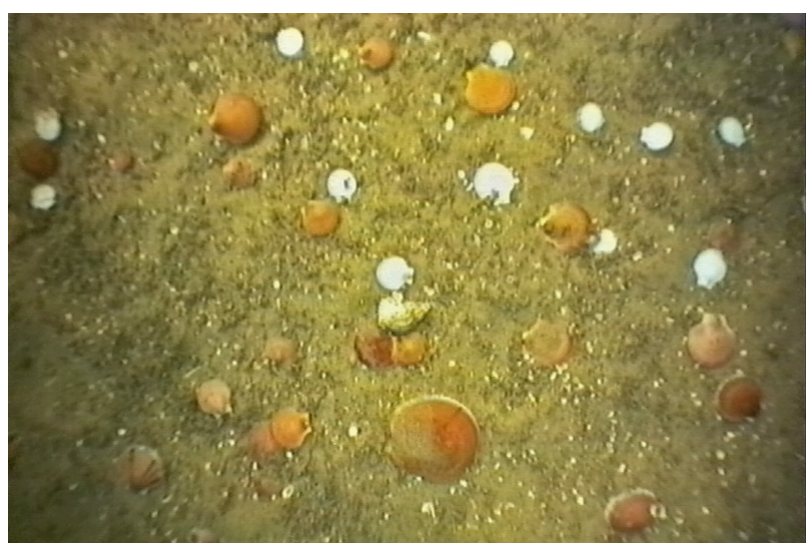


Table 1. Placopecten magellanicus. Number of stations sampled (4 deployments were made at each station), mean number of scallops, standard error (SE), mean shell height (SH), and mean meat weight (MW) of all scallop sizes observed, estimated total scallop abundance (TA), and 95\% confidence limits (CL) in billions, annually from 2003 to 2009

\begin{tabular}{|lccccccc|}
\hline Year & $\begin{array}{c}\text { No. of } \\
\text { stns }\end{array}$ & $\begin{array}{c}\text { Mean no. } \\
\left(\mathrm{m}^{-2}\right)\end{array}$ & SE & $\begin{array}{c}\text { Mean SH } \\
(\mathrm{mm})\end{array}$ & $\begin{array}{c}\text { Mean MW } \\
(\mathrm{g})\end{array}$ & $\begin{array}{c}\text { TA } \\
\left(\times 10^{9}\right)\end{array}$ & $\begin{array}{c}95 \% \\
\text { CL }\end{array}$ \\
\hline \multicolumn{2}{l}{ Mid-Atlantic } & & & & & & \\
2003 & 799 & 0.71 & 0.14 & 59 & 4.67 & 17.42 & 6.90 \\
2004 & 829 & 0.23 & 0.03 & 85 & 11.67 & 5.94 & 1.32 \\
2005 & 860 & 0.22 & 0.03 & 87 & 14.12 & 5.79 & 1.39 \\
2006 & 872 & 0.20 & 0.02 & 93 & 16.01 & 5.52 & 1.14 \\
2007 & 931 & 0.22 & 0.02 & 90 & 14.04 & 6.33 & 1.20 \\
2008 & 913 & 0.22 & 0.02 & 91 & 16.95 & 6.09 & 1.15 \\
2009 & 928 & 0.13 & 0.01 & 98 & 19.93 & 3.61 & 0.51 \\
Georges Bank & & & & & & \\
2003 & 904 & 0.17 & 0.02 & 88 & 14.07 & 4.74 & 0.95 \\
2004 & 921 & 0.13 & 0.01 & 101 & 20.85 & 3.57 & 0.79 \\
2005 & 902 & 0.10 & 0.01 & 111 & 27.95 & 2.79 & 0.70 \\
2006 & 916 & 0.14 & 0.01 & 109 & 27.24 & 3.99 & 0.79 \\
2007 & 901 & 0.20 & 0.02 & 80 & 14.16 & 5.49 & 1.20 \\
2008 & 882 & 0.15 & 0.02 & 99 & 24.75 & 4.15 & 1.01 \\
2009 & 942 & 0.16 & 0.02 & 96 & 20.78 & 4.53 & 1.06 \\
\hline
\end{tabular}

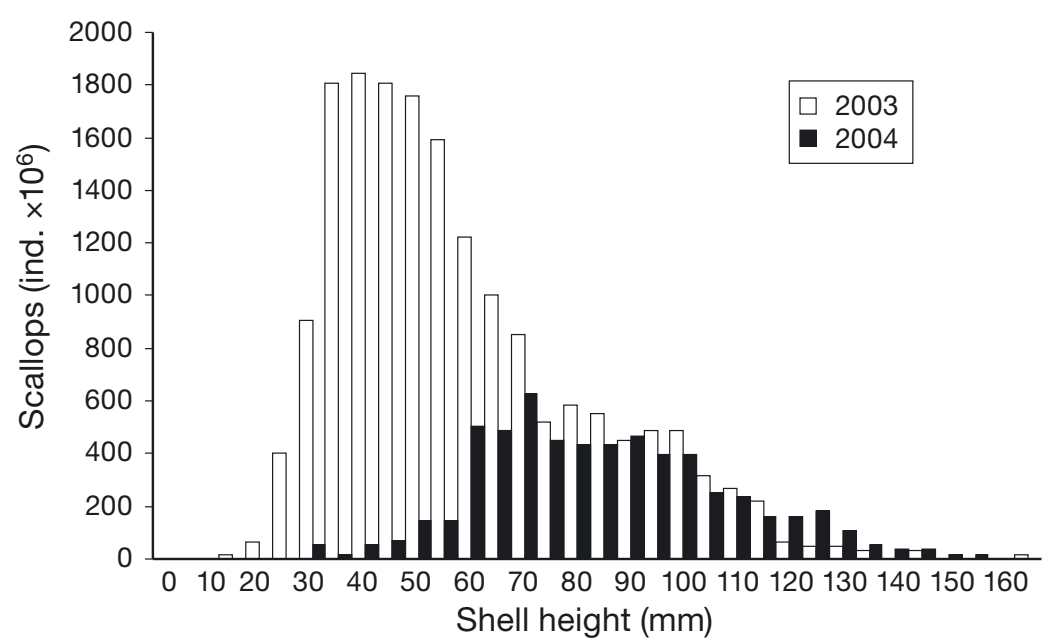

Fig. 3. Placopecten magellanicus. Frequency of shell heights (number of scallops per $5 \mathrm{~mm}$ size class) in the mid-Atlantic for 2003 and for 2004

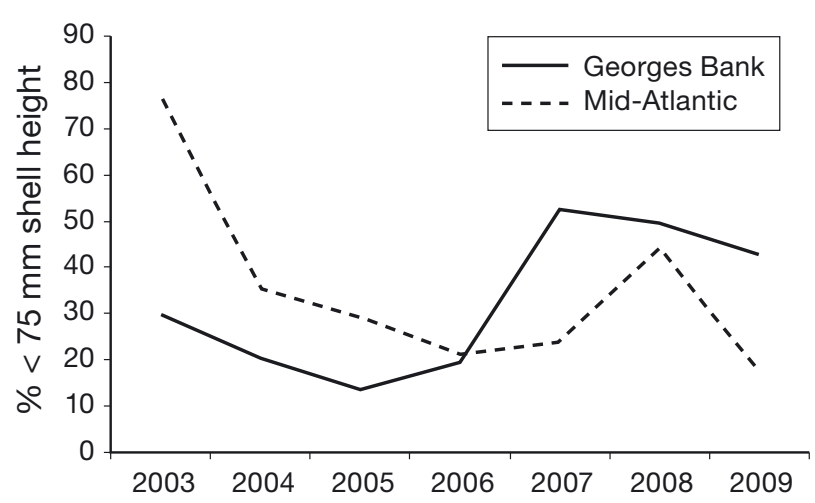

Fig. 4. Placopecten magellanicus. Percentage of scallops $<75 \mathrm{~mm}$ shell height observed from 2003 to 2009 on Georges Bank and in the mid-Atlantic
More than half of the estimated midAtlantic scallop resource vanished between 2003 and 2004, i.e. about $1.15 \times$ $10^{10}$ scallops (Table 1, Figs. $1 \& 3$ ). The highest losses occurred in the areas of highest 2003 scallop recruitment (Fig. 1). Only $1.1 \times 10^{9}$ scallops were accounted for in the landings data (23 533 t from 1 April 2003 to 30 March 2004 using an exploitable meat weight of $22.3 \mathrm{~g}$ ), indicating that an estimated $1.04 \times 10^{10}$ scallops died of natural or incidental fishing mortality. From 2004 through 2009, the number of scallops in the mid-Atlantic remained relatively constant, averaging $5.5 \times 10^{9}$ individuals $\left(\mathrm{SD}=9.9 \times 10^{8}\right)$ (Table 1$)$. The estimated number of scallops $<75 \mathrm{~mm}$ in shell height ranged between 18 and $44 \%$ from 2004 to 2009 (Fig. 4).

Georges Bank averaged $4.2 \times 10^{9}$ scallops $\left(\mathrm{SD}=8.7 \times 10^{8}\right)$ from 2003 to 2009 (Table 1). The number of scallops $<75 \mathrm{~mm}$ in shell height ranged from 14 to $50 \%$ from 2003 to 2009 , with recruitment increasing from 2007 to 2009 (Fig. 4).

\section{DISCUSSION}

The large recruitment event of Placopecten magellanicus, observed in June 2003 in the mid-Atlantic, represented a doubling of the United States' scallop resource. However, this large recruitment was reduced by more than half, a loss on the order of 10.4 billion scallops, between June 2003 and July 2004. This mass mortality was equivalent to the total number of scallops on Georges Bank and in the mid-Atlantic combined in any given year from 2004 to 2009.

Natural mass mortalities in sea scallop populations may be caused by extremes in the physical environment, such as temperature change, or biological factors, such as predation or the effects of senescence, including parasitism by shell borers and prokaryotic infection (Dickie \& Medcof 1963, Stokesbury et al. 2007).

Dickie \& Medcof (1963) observed that extreme shifts in water temperature resulted in $80 \%$ of the scallops perishing in scallop beds throughout the southwestern Gulf of St. Lawrence and Bay of Fundy. The average near-bottom temperature in August on the mid-Atlantic 
shelf, where the 2003 recruitment occurred, is 8 to $12^{\circ} \mathrm{C}$ (Drinkwater \& Mountain 1997). The sea scallop's optimal temperature is $10^{\circ} \mathrm{C}$ (Dickie 1958). Although the bottom-water temperature at the site of the mortality event is unknown, a large number of these recruited scallops did survive, suggesting that the mortality was not caused by an extreme temperature shift.

Responses of predators to prey abundance include functional responses, in which the consumption rates of individual predators increase, and aggregative numerical responses, in which the densities of predators increase (Barbeau et al. 1996, Wong \& Barbeau 2005). Predation rates on small scallops can be very high, particularly from crabs and sea stars (Barbeau et al. 1994, Stokesbury \& Himmelman 1995, Hart 2006, Marino et al. 2007, 2009).

Crab densities had no significant effect on scallop recruitment in the mid-Atlantic from 2000 to 2002 (Hart 2006). Similarly, few crabs were observed at the 76 stations with high scallop density; averaging 0.05 crabs $\mathrm{m}^{-2}$ in $2003\left(\mathrm{SE}=0.016\right.$ ) and $0.03 \mathrm{crabs} \mathrm{m}^{-2}$ in 2004 $(\mathrm{SE}=0.013)$. Even with the increase in consumption rates observed in laboratory experiments when crabs were exposed to high densities of juvenile scallops (crabs ate 3 scallops daily; Nadeau et al. 2009), it is not likely that crab predation caused the decline in scallop density observed between 2003 and 2004 .

Sea stars were the most abundant invertebrate observed in the mid-Atlantic survey area, averaging 2.52 sea stars $\mathrm{m}^{-2}$ in $2003(\mathrm{SE}=0.118)$ and 2.26 sea stars $\mathrm{m}^{-2}$ in 2004 ( $\mathrm{SE}=0.116)$; however, densities were lower within the area of high scallop recruitment, averaging 2.06 sea stars $\mathrm{m}^{-2}$ in $2003(\mathrm{SE}=0.329)$ and 1.27 sea stars $\mathrm{m}^{-2}$ in 2004 (SE $\left.=0.198\right)$. Astropecten americanus occurred at high abundance below $75 \mathrm{~m}$ water depth, while Asteria spp. densities were higher in shallower water to the west of the high scallop recruitment area (Hart 2006). Sea star densities in the area of high scallop recruitment were similar to those in other areas on Georges Bank and in the mid-Atlantic that did not experience a drastic decrease in density (Stokesbury et al. 2004, Marino et al. 2007).

Senescence was not a likely cause of the mortality episode, as these scallops were young, based on their shell heights, and appeared to be in good physical condition. Scallop shells observed in the video survey were clear of fouling organisms such as sponges (Fig. 2). We observed these scallops swimming vigorously in 2003 and 2004.

Food limitation can occur in scallop aggregations, resulting in the scallops spacing themselves out (MacDonald \& Bajdik 1992), and in slower growth rates (Schick et al. 1988). Scallops in the 2003 recruitment event were extremely dense, averaging 5.28 scallops $\mathrm{m}^{-2}(\mathrm{SE}=1.39)$ and, in some quadrats, $>40$ scallops $\mathrm{m}^{-2}$, with little space between individuals (Fig. 2). We also observed a large scallop recruitment event in the Gulf of Maine with similar high densities, >50 scallops $\mathrm{m}^{-2}$ in some quadrats, in August 2009 (Stokesbury et al. 2010). In August 2010, scallop densities were still very high, and the cohort's shell height had increased an average of $10 \mathrm{~mm}$ (K. D. E. Stokesbury et al. unpubl. data), suggesting that natural mortality induced by food limitation had not occurred. The Gulf of Maine and the mid-Atlantic are different systems, but this suggests that densities in the mid-Atlantic were not high enough to induce mortality due to food limitation.

Fishing effort was highly focused in the midAtlantic, as large areas of Georges Bank, containing $48 \%$ of the scallop resource, were closed to harvesting. Of the $28931 \mathrm{t}$ of scallop meat landed from March 2003 to February 2004, 81 \% (23533 t) were harvested from the mid-Atlantic (NMFS 2010).

The offshore sea scallop fishing fleet has used the same technique for harvesting since the 1930s (Stevenson 1936, Bourne 1964, Caddy 1989). New England fishing vessels (25 to $30 \mathrm{~m}$ ) typically deploy $2 \mathrm{New}$ Bedford offshore dredges, each weighing about $1870 \mathrm{~kg}$, with a width of $4.5 \mathrm{~m}$, a series of vertical and horizontal sweep chains preventing large rocks from entering the bag, a $20.3 \mathrm{~mm}$ diamond mesh twine top for fish escapement, a $4.5 \times 0.8 \mathrm{~m}$ bag knit of $89 \mathrm{~mm}$ steel rings (increased to $102 \mathrm{~mm}$ in 2004), and rubber chaffing gear (Stokesbury \& Harris 2006). The dredges are towed for 10 to $50 \mathrm{~min}$, hauled to the surface, and poured on deck. The catch is sorted, and rocks, small scallops, and unwanted fish are removed by hand and discarded overboard. The remaining scallops are processed at sea; the meat is removed and placed in bags on ice, but the shell and soft tissue are discarded overboard. There is a 7 person limit on each fishing trip, 3 per watch with 1 overlapping. Thus, with the captain or mate in the wheel house, there are usually only 2 to 3 crew members on deck to process the catch. A full dredge can take several hours to clear and process. Further, multiple tows may be poured on deck, allowing the vessel to lay and shuck scallops for 10 to $12 \mathrm{~h}$; this increases productivity and reduces fuel costs.

The disappearance of 10.4 billion scallops was probably caused by incidental fishing mortality. During fishing these small scallops were exposed to warm water and air temperatures for several hours as they were brought to the surface and sorted on deck before being returned to the sea floor. For scallops living in water from 8 to $12^{\circ} \mathrm{C}$, the incipient lethal temperature is from 21 to $22^{\circ} \mathrm{C}$ and the maximum upper lethal temperature is $23.5^{\circ} \mathrm{C}$ (Dickie 1958, Dickie \& Medcof 1963). The surface water temperature averaged between 22 and $23^{\circ} \mathrm{C}$ from July to September 2003 in the mid-Atlantic (NOAA Buoys 44009 and 44014), while 
air temperatures were frequently $\geq 30^{\circ} \mathrm{C}$. Fishermen confirmed that large numbers of small scallops were piled on deck for several hours before being shoveled overboard as catches were large, the ring size was $89 \mathrm{~mm}$, and sorting for the large scallops was slow. Exposure to high air temperature $\left(>28^{\circ} \mathrm{C}\right)$ for as little as 20 min resulted in $96 \%$ mortality of the crab Liocarcinus depurator collected as bycatch in the rapido trawl fishery in the northern Adriatic Sea (Giomi et al. 2008).

We reported the 2003 recruitment event to the New England Fisheries Management Council (NEFMC) Scallop Plan Development Team on 2 July 2003. The video survey data agreed with the National Marine Fisheries Service preliminary dredge survey data and the Scallop Plan Development Team advised closing the area (Stokesbury et al. 2004). The fishing industry also supported the closure provided that access to the closed areas on Georges Bank was allowed. The NEFMC used Amendment 10 to the sea scallop fisheries management plan to create the Elephant Trunk Closed Area and limited access to Georges Bank closed areas. The closure went into effect on 23 July 2004, 13 mo after the data were first presented (50 CFR 648 2004). Despite the loss of small scallops, the Elephant Trunk Closed Area contained 41475 t of scallop meat in 2005 and has provided substantial landings for the past $5 \mathrm{yr}$.

An earlier closure and a shift of effort to Georges Bank might have been beneficial; it may have reduced the incidental fishing mortality in the mid-Atlantic and avoided a mass natural mortality of scallops, which occurred 1 yr later, between 2004 and 2005, in the Nantucket Lightship Closed Area. In this mass mortality episode, $0.2 \times 10^{9}$ scallops perished, equal to approximately $6484 \mathrm{t}$ of harvestable scallop meat (equivalent to $\$ 100$ million USD ex-vessel). These were large scallops that appeared to suffer the effects of senescence, including parasitism by shell borers and prokaryotic infection, which likely caused the mass mortality (Stokesbury et al. 2007).

The recovery of the sea scallop fishery is a management success, as the stock is above the estimated maximum sustainable yield (NMFS 2010). However, had managers been able to respond to timely information, the resource may potentially have been much larger. Large recruitment pulses in marine populations are common and conducive to significant changes in abundance. A historic example is the tilefish Lopholatilus chamaeleonticeps, which suffered a massive die off $\left(>1.5 \times 10^{9}\right.$ dead tilefish floating on the surface from the Great South Channel to Delaware Bay) due to an abnormal flood of cold water along the mid-Atlantic continental shelf in 1882. The tilefish was feared extinct, and no samples were collected until 1892, but by 1915 a full fishery was operating, landing $4500 \mathrm{t}$
(Bigelow \& Schroeder 2002). A recent example is the haddock Melanogrammus aeglefinus stock of Georges Bank, which had an extremely large year class in 2003 $\left(3.6 \times 10^{8} 1 \mathrm{yr}\right.$ olds estimated in 2004) and increased stock biomass to $315975 \mathrm{t}$ by 2007, twice the estimated biomass for sustainable yield ( $\left.B_{\text {msy }}\right)$ (NMFS 2008). These examples of large recruitment events also suggest that marine populations may not grow at a constant rate, and instantaneous rates or weighted averages of recruitment in population models may inaccurately describe population dynamics. Achieving the full benefit of exceptional recruitment events requires a closer examination of target species ecology, real-time abundance, and size distribution data, and a management system that can respond rapidly.

Acknowledgements. We thank the owners, captains and crews who sailed with us. R. Tian summarized the NOAA buoy temperature data. M. Stokesbury and 4 anonymous reviewers provided insightful comments on the manuscript. Aid was provided by NOAA awards (NA04NMF4720332, NA04NMF4721131, NA05NMF4540012, NA06NMF4720097, NA08NMF4720554, and NA09NMF4720256), the sea scallop fishery, and supporting industries. The views expressed herein are those of the authors and do not necessarily reflect the views of the NOAA or any other agencies.

\section{LITERATURE CITED}

Barbeau MA, Scheibling RE, Hatcher BG, Taylor LH, Hennigar AW (1994) Survival analysis of tethered juvenile sea scallops Placopecten magellanicus in field experiments: effects of predators, scallop size and density, site and season. Mar Ecol Prog Ser 115:243-256

Barbeau MA, Hatcher BG, Scheibling RE, Hennigar AW, Taylor LH, Risk AC (1996) Dynamics of juvenile sea scallop (Placopecten magellanicus) and their predators in bottom seeding trials in Lunenburg Bay, Nova Scotia. Can J Fish Aquat Sci 53:2494-2512

Bigelow HB, Schroeder WC (2002) Fishes of the Gulf of Maine, 3rd edn. Smithsonian Institution Press, Washington, DC

Bourne N (1964) Scallops and the offshore fishery of the Maritime Provinces. Fish Res Board Can 145:1-60

Caddy JF (1971) Recent scallop recruitment and apparent reduction in cull size by the Canadian fleet on Georges Bank. ICNAF Res Doc 71/84:147-155

Caddy JF (1972) Size selectivity of the Georges Bank offshore dredge and mortality estimated for scallops from the northern edge of Georges in the period June 1970 to 1971. ICNAF Res Doc 72/5:79-85

Caddy JF (1989) A perspective on the population dynamics and assessment of scallop fisheries, with special reference to sea scallop, Placopecten magellanicus (Gmelin). In: Caddy JF (ed) Marine invertebrate fisheries: their assessment and management. John Wiley \& Sons, New York, NY, p 559-589

Cochran WG (1977) Sampling techniques. John Wiley \& Sons, New York, NY

Dickie LM (1958) Effects of high temperature on survival of the giant scallop. Fish Res Board Can 15:1189-1211

Dickie LM, Medcof JC (1963) Cause of mass mortalities of scallops (Placopecten magellanicus) in the southwestern Gulf of St. Lawrence. J Fish Res Board Can 20:451-482 
Drinkwater KF, Mountain DG (1997) Climate and oceanography. In: Boreman J, Nakashima BS, Wilson JA, Kendall RL (eds) Northwest Atlantic groundfish: perspectives on a fishery collapse. American Fisheries Society, Bethesda, MD, 3-25

Giomi F, Raicevich S, Giovanardi O, Pranovi F, Di Muro P, Beltramini M (2008) Catch me in winter! Seasonal variation in air temperature severely enhances physiological stress and mortality of species subjected to sorting operations and discarded during annual fishing activities. Hydrobiologia 606:195-202

Harris BP, Stokesbury KDE (2006) Shell growth of sea scallops (Placopecten magellanicus) in the southern and northern Great South Channel, USA. ICES J Mar Sci 63:811-821

Hart DR (2006) Effects of sea stars and crabs on sea scallop Placopecten magellanicus recruitment in the Mid-Atlantic Bight (USA). Mar Ecol Prog Ser 306:209-221

Hart DR, Rago PJ (2006) Long-term dynamics of U.S. Atlantic sea scallop Placopecten magellanicus populations. N Am J Fish Manag 26:490-501

Krebs CJ (1989) Ecological methodology. Harper \& Row, New York, NY

Langton RW, Robinson WE, Schick D (1987) Fecundity and reproductive effort of sea scallops Placopecten magellanicus from the Gulf of Maine. Mar Ecol Prog Ser 37:19-25

MacDonald BA, Bajdik CD (1992) Orientation and distribution of individual Placopecten magellanicus (Gmelin) in two natural populations with differing production. Can J Fish Aquat Sci 49:2086-2092

MacDonald BA, Thompson RJ (1985) Influence of temperature and food availability on the ecological energetics of the giant scallop Placopecten magellanicus. II. Reproductive output and total production. Mar Ecol Prog Ser 25:295-303

Marino MC II, Juanes F, Stokesbury KDE (2007) Effect of closed areas on populations of sea star Asterias spp. on Georges Bank. Mar Ecol Prog Ser 347:39-49

- Marino MC II, Juanes F, Stokesbury KDE (2009) Spatiotemporal variations of sea star Asterias spp. distributions between sea scallop Placopecten magellanicus beds on Georges Bank. Mar Ecol Prog Ser 382:59-68

> McGarvey R, Serchuk FM, McLaren IA (1992) Statistics of reproduction and early life history survival of the Georges Bank sea scallop (Placopecten magellanicus) population. J Northwest Atl Fish Sci 13:83-99

Merrill AS, Posgay JA (1964) Estimating the natural mortality rate of sea scallop (Placopecten magellanicus). ICNAF Res Bull 1:88-106

Murawski S, Serchuk F (1989) Environmental effects of offshore dredge fisheries for bivalves. ICES CM 1989/K:27

> Myers RA, Fuller SD, Kehler DG (2000) A fisheries management strategy robust to ignorance: rotational harvest in the presence of indirect fishing mortality. Can J Fish Aquat Sci 57:2357-2362

Nadeau M, Barbeau MA, Brêthes JC (2009) Behavioural mechanisms of sea stars (Asterias vulgaris Verrill and Leptasterias polaris Müller) and crabs (Cancer irroratus Say and Hyas araneus Linnaeus) preying on juvenile sea scallops (Placopecten magellanicus (Gmelin)), and procedural effects of scallop tethering. J Exp Mar Biol Ecol 374: $134-143$

Editorial responsibility: Matthias Seaman, Oldendorf/Luhe, Germany
NMFS (National Marine Fisheries Service, Northeast Fisheries Science Center) (2008) Georges Bank haddock. Assessment of 19 northeast groundfish stocks through 2007: 3rd groundfish assessment review meeting (GARM III). Ref Doc 08-15, US Dept Commerce, Northeast Fisheries Science Center, Woods Hole, MA, p 884

NMFS (National Marine Fisheries Service Northeast Fisheries Science Center) (2010) Atlantic sea scallop stock assessment for 2010. 50th northeast regional stock assessment workshop (50th SAW) assessment report. Ref Doc 10-17, US Dept Commerce, Northeast Fisheries Science Center, Woods Hole, MA, p 844

Posgay JA (1981) Movement of tagged sea scallops on Georges Bank. Mar Fish Rev 43:19-25

Rago P, Murawski S, Stokesbury KDE, DuPaul W, McSherry $M$ (2000) Integrated management of the sea scallop fishery in the northeast USA: research and commercial vessel surveys, observers, and vessel monitoring systems. ICES CM 2000/W:13

Schick DF, Shumway SE, Hunter MA (1988) A comparison of growth rates between shallow water and deep water populations of scallops, Placopecten magellanicus (Gmelin, 1791), in the Gulf of Maine. Am Malacol Bull 6:1-8

Stevenson JA (1936) The Canadian scallop: its fishery, lifehistory and some environmental relationships. MS thesis, University of Western Ontario, Waterloo, ON

Stokesbury KDE (2002) Estimation of sea scallop abundance in closed areas of Georges Bank, USA. Trans Am Fish Soc 131:1081-1092

Stokesbury KDE, Harris BP (2006) Impact of limited shortterm sea scallop fishery on epibenthic community of Georges Bank closed areas. Mar Ecol Prog Ser 307:85-100

Stokesbury KDE, Himmelman JH (1995) Biological and physical variables associated with aggregations of the giant scallop Placopecten magellanicus. Can J Fish Aquat Sci 52:743-753

> Stokesbury KDE, Himmelman JH (1996) Experimental examination of movement of the giant scallop, Placopecten magellanicus. Mar Biol 124:651-660

Stokesbury KDE, Harris BP, Marino MC II, Nogueira JI (2004) Estimation of sea scallop abundance using a video survey in off-shore USA waters. J Shellfish Res 23:33-44

Stokesbury KDE, Harris BP, Marino MC II, Nogueira JI (2007) Sea scallop mass mortality in a marine protected area. Mar Ecol Prog Ser 349:151-158

Stokesbury KDE, Carey JD, Harris BP, O'Keefe CE (2010) High juvenile sea scallop (Placopecten magellanicus) densities on banks and ledges in the Central Gulf of Maine. J Shellfish Res 29:369-372

USA Federal Regulations (2004) Fisheries of the northeastern United States: Atlantic sea scallop fishery, Amendment 10. USA Fed Reg 69 120/23 June 2004, 50 CFR Part 648

> Wong MC, Barbeau MA (2005) Prey selection and the functional response of sea stars (Asterias vulgaris Verrill) and rock crabs (Cancer irroratus Say) preying on juvenile sea scallops (Placopecten magellanicus (Gmelin)), and blue mussels (Mytilus edulis Linnaeus). J Exp Mar Biol Ecol 327: $1-21$

Yochum N, DuPaul WD (2008) Size-selectivity of the northwest Atlantic sea scallop (Placopecten magellanicus) dredge. J Shellfish Res 27:265-271

Submitted: October 14, 2010; Accepted: January 3, 2011 Proofs received from author(s): March 2, 2011 